\title{
Success attitudes of young ophthalmologists in the first decade of their career
}

\author{
Atitudes de sucesso de jovens oftalmologistas na primeira década da carreira
}

Fernando Rodrigo Pedreira Chaves ${ }^{1}$, Carlos Eduardo Leite Arieta ${ }^{1}$, Maurício Abujamra Nascimento ${ }^{1}$, Keila Miriam Monteiro de Carvalho², Rodrigo Pessoa Cavalcanti Lira ${ }^{1}$

\section{ABSTRACT}

Purpose: To describe the main success attitudes of young ophthalmologists in the first decade of their career

Methods: This descriptive study comprised subjects selected from a sample of ophthalmologists who were participating in a congress, using a semi-structured questionnaire. The inclusion criteria were as follows: ophthalmologists under the age of 40 years, within 5-10 years from ophthalmology residency conclusion. The subjects were asked about the three main success attitudes in their personal experience during the first years of ophthalmology practice. After the initial results, the 10 most frequently mentioned attitudes were listed and volunteers were again interviewed to choose, within the latter list, the three main attitudes.

Results: Forty-eight ophthalmologists were interviewed, 24 (50\%) were male; the mean age was 37 years (SD: 2 years, range: 33-40 years) and the mean time from ophthalmology residency conclusion was 8 years (SD: 1 year, range: 5-10 years). The frequency of such mentioned success attitudes were as follows: to invest in professional updating (22.9\%), to have a good relationship with patients and professional partners (18.8\%), to prioritize individual and family happiness (12.5\%), initially to work in an established group (11.1\%), to work in public service (9.7\%), to have their own business with a homogeneous group (7.6\%), to save money (7.6\%), to be ready to resume work (4.2\%), to get business administration skills (4.2\%), and to have professional insurance $(0.7 \%)$.

Conclusions: The three main success attitudes consisted in investing in professional updating (22.9\%), maintaining a good relationship with patients and professional partners (18.8\%), and prioritizing individual and family happiness (12.5\%). Although these results should not be generalized, they are helpful not only for those ophthalmologists at the beginning of a career but also those who want to reflect on what to prioritize in their professional practice.

Keywords: Professional practice; Education, medical, continuing; Ophthalmology/ manpower; Job market; Health management

\section{RESUMO}

Objetivos: Descrever as principais atitudes de sucesso de jovens oftalmologistas na primeira década de exercício da profissão.

Métodos: Tratou-se de um estudo descritivo. Os sujeitos da pesquisa foram selecionados a partir de amostra de participantes de congresso de oftalmologia, utilizando-se questionário semi-estruturado. Os critérios de inclusão foram: médico oftalmologista com menos de 40 anos e que tivesse entre 5 e 10 anos de conclusão da residência médica. Questionou-se sobre quais foram as três principais atitudes de sucesso na experiência pessoal durante esses primeiros anos do exercício da medicina. Após os resultados iniciais, foram relacionadas as dez atitudes mais citadas e os voluntários foram mais uma vezentrevistados para queescolhessem, dentro destaúltima listagem, as três principais atitudes.

Resultados: Foram entrevistados 48 oftalmologistas, destes 24 (50\%) eram do gênero masculino, a média da idade foi 37 anos (DP 2 anos, intervalo de 33 a 40 anos) e a média do tempo de conclusão do curso de 8 anos (DP 1 ano, intervalo de 5 a 10 anos). A frequência de citação das atitudes de sucesso foi: investir continuadamente na formação profissional (22,9\%), manter bom relacionamento com pacientes e colegas de profissão (18,8\%), priorizar a felicidade individual e familiar (12,5\%), inicialmente prestar serviço para grupo estabelecido (11,1\%), ingressar no serviço público (9,7\%), montar consultório próprio junto a grupo homogêneo (7,6\%), hábito de poupança (7,6\%), estar pronto para o recomeço profissional (4,2\%), investir na formação complementar em administração (4,2\%), e contratação de seguro profissional $(0,7 \%)$.

Conclusões: As três principais atitudes foram: investir continuadamente na formação profissional, manterbom relacionamento compacientes e colegas de profissão, epriorizar a felicidade individual efamiliar. Embora estes resultados não devam seruniversalmente generalizados, eles ajudam não apenas aos ingressantes na profissão, mas todo oftalmologista que deseja refletir sobre o que priorizar em seu exercício profissional.

Descritores: Prática profissional; Educação médica continuada; Oftalmologia/recursos humanos; Mercado de trabalho; Gestão em saúde

\section{INTRODUCTION}

Ophthalmologists face the challenge of reconciling a good clinical practice, focused on respect for the patient and the constant updating of their knowledge, with the need to occupy their place in the job market and promote their social relationship ${ }^{(1,2)}$.

Perhaps this is most evident in the early years of professional activity, when good decisions will have a positive effect on success as a physician and as an individual within a social context. This study aimed to describe the main attitudes to achieve success that the young ophthalmologists considered to be important during the first decade of their profession.

\section{METHODS}

We conducted a descriptive study with physicians from all over Brazil, who participated in a Congress of Ophthalmology in June 2011, using semi-structured interviews. Inclusion criteria were as follows: being medical ophthalmologist under 40 years of age, having completed more than 5 and less than 10 years of specialization in ophthalmology (accredited by the Ministry of Education and Culture of Brazil - MEC - and/or the Brazilian Council of Ophthalmology - CBO).

From the database entries of the congress, participants who met the inclusion criteria were randomly invited to answer two questionnaires. In the first questionnaire, by e-mail, we collected data on 
gender, age, time of completion of specialization, and answer to the following question: what were the three main success attitudes in your personal experience during the exercise of ophthalmology? Success attitudes were defined as the personal choices made at the beginning of the career that contributed positively to professional success. After accounting for initial results, the 10 most frequently cited attitudes were listed.

In the second questionnaire, the same volunteers were once again interviewed by e-mail and asked to choose, within this new 10-item list, the three main attitudes in their experience. The order of presentation of the options was randomly different for each respondent to provide equal exposure of each item. The study protocol was approved by the Research Ethics Committee/Investigational Review Board, under number CAAE 0842.0.146.000-11.

The results of these analyzes were presented with descriptive statistics using SPSS software. The central tendency was determined by the mean and standard deviation. Categorical data were analyzed using Chi-square test and Fisher's exact test, and $p<5 \%$ was considered significant.

\section{RESULTS}

Forty-eight ophthalmologists were interviewed, with a mean age of 37 years (SD: 2 years, range: 33-40 years) and a mean completion time of specialization in ophthalmology of 8 years (SD: 1 year, range: 5-10 years). Twenty-four (50\%) were male and all of them agreed to participate in the study. Table 1 details the frequency of mention of success attitudes (144 citations $=3$ per respondent).

\section{DISCUSSION}

The item most often mentioned in the study was to invest in professional up to dating. When we looked up at the literature, we concluded that with increasing access to information, professionals have been evaluated not only by their initial training but also their capacity to keep updated and to adapt to new demands ${ }^{(1,3)}$.

One of the ways to invest in professional up to dating is continuing medical education (CME). Despite CME does not have an exact match in the official Brazilian educational system, it has become increasingly familiar to professionals in medicine ${ }^{(4)}$, and is an important form of ongoing education for professionals in the $21^{\text {st }}$ century, especially in the health field, where the volume of scientific information grows exponentially ${ }^{(5.6)}$. Unfortunately, as the time since graduation in Medicine increases, updated knowledge of healthcare decreases, showing a statistically significant negative correlation between these variables ${ }^{(7)}$. A study with three groups of former residents, all graduates from the same institution, with titles of specialists in ophthalmology from the Brazilian Council of Ophthalmology (CBO), acquired one, 5 , and 10 years before, respectively, showed a significant decrease in retention of theoretical knowledge over the years ${ }^{(8)}$.

Maintaining good relationships with patients and professional colleagues was the second most frequently mentioned item, while having professional insurance received one single mention. This ratio faithfully represents what is found in the literature regarding civil responsibility of the physician ${ }^{(9,10)}$.

Legal aspects have become increasingly important after the adoption of the Law \# 8078 in the consumer protection code, dated September $11^{\text {th }}, 1990$, with implications for modification of social behavior and consequences in the practice of citizenship. First of all, the law changed the physician into a medical provider, the patient into a consumer, and the practice of medicine into provision of medical services ${ }^{(9)}$. The deterioration of the physician-patient relationship has contributed greatly to the increased number of medical liability lawsuits and a significant proportion of complaints of alleged malpractice before the Medical Council(10).

However, the generally expensive insurance professionals can give a false sense of security, which, in practical terms, does not always correspond to the reality of facts ${ }^{(11)}$. When there is good communication and demonstration of respect for the patient's feelings and opinions, he/she participates in decisions and consequently more readily accepts the results of treatment, even when not satisfactory ${ }^{(10)}$.

Thus, despite professional insurance having its importance in protecting medical activity in a context of possible adverse events, the physician-patient relationship still assumes the lead role in managing unwanted events during the therapeutic process $s^{(1,2,12,13)}$.

Relationships between co-workers also had great importance for a considerable number of study participants. The work environment provides numerous personal and professional interactions with potential mutual benefits among individuals who invest in this relationship ${ }^{(14)}$. Networking, therefore, becomes extremely relevant to professional ascension. In a society where solutions are required immediately and there is no time for failed attempts, the practice of resorting to those one already known prevails in more than $90 \%$ of cases $^{(15)}$. Most success stems from long-term relationships, and this represents a competitive advantage that cannot be overlooked ${ }^{(16)}$.

The third most-mentioned item was to prioritize individual and family happiness. Studies suggest that individuals who consider themselves happy set more ambitious goals, perform better at work, and continue longer in tasks that require persistence ${ }^{(17)}$.

Table 1. Success attitudes of young ophthalmologists in the first decade of their career

\begin{tabular}{|c|c|c|c|c|}
\hline Item & $\begin{array}{l}\text { Frequency } \\
\quad \mathrm{N}(\%)\end{array}$ & $\begin{array}{l}\text { Male } \\
\text { N (\%) }\end{array}$ & $\begin{array}{c}\text { Female } \\
\text { N (\%) }\end{array}$ & $\begin{array}{c}P \\
\text { value }\end{array}$ \\
\hline To invest in professional up to dating & $33(22.9)$ & $18(25.0)$ & $15(20.8)$ & $0.55^{\mathrm{a}}$ \\
\hline To have a good relationship with patients and professional partners & $27(18.8)$ & $8(11.1)$ & $19(26.4)$ & $0.02^{\mathrm{a}}$ \\
\hline \multirow{2}{*}{$\begin{array}{l}\text { To prioritize individual and family happiness initially to work in an } \\
\text { established group }\end{array}$} & $18(12.5)$ & $4(5.5)$ & $14(19.4)$ & $0.02^{\mathrm{b}}$ \\
\hline & $16(11.1)$ & $8(11.1)$ & $8(11.1)$ & $0.99^{a}$ \\
\hline To work in public service & $14(9.7)$ & $11(15.3)$ & $3(4.2)$ & $0.04^{\mathrm{b}}$ \\
\hline To have an own business with a homogeneous group & $11(7.6)$ & $9(12.5)$ & $2(2.8)$ & $0.05^{b}$ \\
\hline To save money & $11(7.6)$ & $5(6.9)$ & $6(8.4)$ & $0.75^{\mathrm{a}}$ \\
\hline To be ready to resume work & $7(4.9)$ & $2(2.8)$ & $5(6.9)$ & $0.44^{b}$ \\
\hline To get business administration skills & $6(4.2)$ & $6(8.4)$ & $0(0)$ & $0.03^{b}$ \\
\hline To have professional insurance & $1(0.7)$ & $1(1.4)$ & $0(0)$ & $0.99^{\mathrm{b}}$ \\
\hline Total & $144(100)$ & $72(100)$ & $72(100)$ & \\
\hline
\end{tabular}

${ }^{a}=$ Chi-square test ${ }^{b}=$ Fisher's exact test 
The challenge of balancing life events with a career trajectory is an important determinant leading to premature dropout or slower career advancement. Family-friendly policies may increase career satisfaction ${ }^{(18)}$

In Brazil, many physicians are dissatisfied with their career. In a research conducted with these professionals, $80 \%$ of respondents considered the medical practice overwhelming due to factors such as overwork, low payment, excessive professional responsibility, poor working conditions, physician-patient relationship turmoil, and loss of autonomy ${ }^{(19)}$.

Among the forms of entry into the job market, some factors were highlighted, such as working in established private groups and public service. A study conducted in 2002 with 7,008 physicians active in public health care in northeastern Brazil showed that $69.7 \%$ work in public sector, $59.3 \%$ in private sector, and $74.7 \%$ in private offices; in other words, physicians often maintain more than one type of insertion into the job market. As a rule, entry into the career occurs by the public sector, and wage earning (public and private) is usually associated with professional work ${ }^{(20)}$.

Office management for several physicians forming a homogeneous group appears as a competitive advantage, as long as principles like impartiality and professionalism among members in all segments and sectors of the clinic/company are adhered to ${ }^{(21)}$. This includes combating nepotism and adopting corporate behavior over personal choices.

A lack of financial literacy can affect people's quality of life ${ }^{(22)}$, as well as postpone the formation of pension savings and cause increased uncertainty regarding the risk and profit of investment products ${ }^{(22,23)}$. Controlling personal and professional compulsive consumption and making savings a habit represent the two major challenges in the management of personal finances ${ }^{(24-27)}$.

The failure situation provides valuable information about actions to be avoided to pursue opportunities in the future and successfully reach goals. Difficulty in achieving a goal can be the result of inability to control certain variables. Giving up an initial goal might not mean failure, but rather the chance to concentrate on projects with more feasible levels of control(28).

As in any venture, young physicians should be prepared to implement changes in their professional careers, ranging from job relocation to changes in the area of professional work. Sometimes, despite having a subspecialty, such as retinal surgery, opportunities arise in general ophthalmology. A study was carried out to identify factors influencing graduating ophthalmology residents to pursue subspecialty training or a career in comprehensive ophthalmology. They concluded that several factors influenced career choices among graduating ophthalmology residents. A desire to acquire special skills and perceived prestige and job market were major factors influencing ophthalmology residents to seek subspecialty training. Lifestyle considerations were more important to residents choosing a comprehensive ophthalmology career ${ }^{(29)}$.

The need to professionalize healthcare administration and the frequent problems with receipts of payment of health plans, hospitals, and users have led to an increase in the number of physicians and other professionals seeking to learn from the basics of administration, such as it is offered by Sebrae, to advanced specialization courses, such as an MBA in health management ${ }^{(30)}$.

Although the sample of this study has not been programmed to test gender differences, some interesting findings merit a more detailed analysis. Female physicians value good relationships with patients and colleagues as well as individual and family happiness more than male physicians. Conversely, male phisicians value further training in administration, participation in public service, and setting up their own clinic.

One of the main limitations of this study lies in the fact that it was conducted in an environment of an academic conference, which may have selected physicians who prize continuing medical education. In addition, the sample was not designed to assess differences in the territorial region of operation, post-academic specialization, or subspecialization within the field of ophthalmology.

The authors are unaware of similar descriptive studies that evaluate success attitudes of young ophthalmologists in the first decade of their career in Brazil. Although these results should not be generalized, they not only help those at the beginning of their careers but also every ophthalmologist who wants to reflect on what to prioritize in their professional practice.

\section{REFERENCES}

1. Morinaga CV, Konno SN, Aisawa RK, Vieira JE, Martins MA. Frases que resumem os atributos na relação médico-paciente. Rev Bras Educ Med. 2002;26(1):21-7.

2. Ismael JC. O médico e o paciente: breve história de uma relação delicada. São Paulo: Queiroz Editor; 2002.

3. Leite MT, Carlini AL, Ramos MP, Sigulem D. Educação médica continuada online: potencial e desafios no cenário brasileiro. Rev Bras Educ Med. 2010;34(1):141-9.

4. Bernardo WM, Jatene FB, Nobre MR. Experiência clínica, educação médica continuada e qualidade da atenção em saúde. Rev Assoc Med Bras. 2005;51(2):63-4.

5. Sackett DL, Haynes RB. On the need for evidence-based medicine (EBM Trends). Evidence-Based Medicine. 1995;1:5

6. Accreditation Council for Continuing Medical Education. ACCME [Internet]. Chicago, IL; 2012 [cited 2012 Feb 20]. Available from: http://www.accme.org

7. Sibley JC, Sackett DL, Neufeld V, Gerrard B, Rudnick KV, Fraser W. A randomized trial of continuing medical education. N Engl J Med. 1982;306(9):511-5.

8. Limeira-Soares PH, Lira RP, Paccola M, Arieta CE. Appraisal of the retention of the knowledge for ophthalmology specialists of the Brazilian Ophthalmology Council. Arq Bras Oftalmol. 2006;69(1):47-9.

9. Brasil. Leis, Decretos etc. Código de defesa do Consumidor. São Paulo: Secretaria de Defesa do Consumidor;1990.

10. Ligiera WR. Os princípios da bioética e os limites da atuação médica. Rev Ibero-Am Direito Público. 2005;5(20):410-27.

11. Josef H. Erro médico: "Pré-conceito"?. Einstein. 2004;2(3):228-9.

12. Nassar MR. Princípios de comunicação excelente para o bom relacionamento médico paciente [tese]. São Paulo: Universidade Estadual Paulista; 2003.

13. Pereira MG, Azevedo ES. A relação médico-paciente em Rio Branco/AC sob a ótica dos pacientes. Rev Assoc Med Bras. 2005;51(3):153-7.

14. Mckenna R. Marketing de relacionamento. Rio de Janeiro: Campus;1992.

15. Souza FA. Marketing trends 2004. São Paulo: Makron Books; 2004.

16. Gummesson E. Marketing de relacionamento total: gerenciamento de marketing estratégias de relacionamento e abordagem de CRM para economias de rede. Porto Alegre: Bookman; 2005.

17. Staw BM, Sutton RI, Pelled LH. Employee positive emotions and favorable outcomes at the workplace. Organization Science. 1994;5(1):51-71.

18. Villablanca AC, Beckett L, Nettiksimmons J, Howell LP. Career flexibility and familyfriendly policies: an $\mathrm{NIH}$-funded study to enhance women's careers in biomedical sciences. J Womens Health (Larchmt) 2011;20(10):1485-96.

19. Machado MH. Os médicos no Brasil um retrato da realidade. Rio de Janeiro: Fiocruz: 1997

20. Maciel RH, Santos JB, Sales TB, Alves MA, Luna AP, Feitosa LB. Multiplicidade de vínculos de médicos no Estado do Ceará. Rev Saúde Pública. 2010;44(5):950-56.

21. Rocha T. As 6 características de um bom gerenciamento em um serviço médico com vários sócios [Internet]. [citado 2012 Fev 20]. Disponível em: http://www.sbao.com. br/artigosLeiaMais.php?ID_ARTIGO=00000000068

22. CORECON-PB. Educação é um projeto de todos [Internet]. [citado 2012 Fev 17] Disponível em: http://www.corecon-pb.org.br.

23. Clark RL, D'Ambrosio MB, McDermed AA, Sawant K. Retirement plans and saving decisions: the role of information and education. J Pension Econ Finance. 2006; 5(1):45-67.

24. Perktold C. A cultura da confiança: a história do crédito no Brasil. Belo Horizonte: Arte e Cultura; 2008

25. Bruni AL. Mercados Financeiros: para a certificação profissional ANBID 10. São Paulo: Atlas; 2005

26. Savoia JR, Saito AT, Santana FA. Paradigmas da educação financeira no Brasil. Rev Adm Pública. 2007:41(6):1121-41.

27. Pinheiro RP. Educação financeira e previdenciária, a nova fronteira dos fundos de pensão. São Paulo: Peixoto Neto; 2008.

28. Leahy RL. Como lidar com as preocupações: sete passos para impedir que elas paralisem você. Porto Alegre: Artmed; 2007

29. Gedde SJ, Budenz DL, Haft P, Tielsch JM, Lee Y, Quigley HA. Factors influencing career choices among graduating ophthalmology residents. Ophthalmology. 2005;112(7): 1247-54

30. Bertachini A. Especialização no setor em franca evolução. Gazeta Mercantil 2007 [citado 2012 Fev 23]. Disponível em: http://www.abraidi.com.br/docs/pdf_not/ Especializacao_no_setor_em_franca_evolucao_Gazeta_Mercantil_301107.doc 